\title{
Smart Refrigerators in Return for Energy Efficiency
}

\author{
Yu. V. Baidak, I. A. Vereitina \\ Odessa National Academy of Food Technologies, 112 Kanatnaya str., Odessa, 65039, Ukraine
}

One of the aspects of the global trend in the development of Smart systems is considered in the paper, namely those solutions of the leading manufacturers of electrical household appliances that relate to the implementation of additional intelligent functions to devices in demand by the society - Smart Diagnosis, Smart Grid-ready, Smart Manager, Smart Access, Smart Adapt. It is emphasized that some tasks related to the energy efficiency of devices, the accuracy of testing tools, which should be used as a basis for the Smart System, remained unresolved. So, the built-in additional sensors and chips of "smart" subsystems require the application of additional measures aimed at reducing the power consumption of the device (preferably twice to restore the balance). On the example of the developed innovative electric motor of domestic refrigerator hermetic compressor drive, the existence of the possibilities for a significant increase in its efficiency has been proved. Since intellectual features of Smart System in its Smart Diagnosis dialog box should be based on monitoring data on power efficiency parameters of the device, a new concept for the development of an electric energy counter is proposed.

Keywords: efficiency, refrigerators, smart systems.

\begin{abstract}
Робота торкається одного з аспектів всесвітньої тендениії розвитку Smart System, а саме питання сочіальної значущьсті тих рішень провідних виробників холодильників, щзо відносяться до впровадження зручностей, яких вже сьогодні потребує соиіум, від оснащення ними побутових приладів через застосування можливостей мікропроцесорних систем керування, запрограмованих на виконання інтелектуальних функиій Smart Diagnosis, Smart Grid-ready, Smart Manager,Smart Access, Smart Adapt. Висловлюється думка про минулу $i$ більш важливу тенденцію, пов'язану із енергетичною досконалістю, ефективністю приладів, засобів їх тестування, які мали б бути використані як підгрунтя для Smart System, але залишились невирішеними. На прикладі двигуна приводу герметичного компресора зроблено спробу довести існування можливостей щзодо суттєвого збільшення його ефективності застосуванням навіть вітчизняних розробок. Оскільки інтелектуальні можливості Smart System в ї̈ діалоговому вікні Smart Diagnosis мають спиратися на дані моніторингу енергетичних показників ефективності роботи приладу, пропонується лічильник електричної енергї̈ вітчизняної розробки і виробнищтва.
\end{abstract}

Ключові слова: Побутові холодильники, розумні системи, тенденція розвитку, мікропроцесорні системи, енергетична досконалість, ефективність, асинхронний двигун, компресор, прилад тестування

(C) The Author(s) 2018. This article is an open access publication

This work is licensed under the Creative Commons Attribution 4.0 International License (CC BY) http://creativecommons.org/licenses/by/4.0/

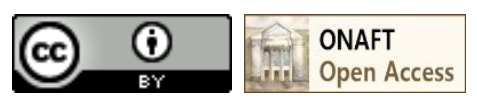

\section{Introduction}

The global trend of development of Smart Systems, which have been around for over last 10 years, was to become a gulp of fresh air at the verge of the transition from power efficiency to power saving [1]. The intention to "teach" the refrigerator to "go" to the store, to order and buy food, to control its quality, to receive information from the supermarket about the availability of food, to communicate with the service center in case of malfunction, to monitor, calculate, and pay the cost of consumed electricity ('smart' tariffs), to recommend meals to eat, to be the third person when communicating with family members, to warm water for washing etc., is not a new one and is intended to further release of the person from the need to make decisions and perform simple everyday routine work. Definitely, for a person with disabilities, such device is a vital thing [2]. As a technical task, it is feasible. Possibilities of modern computer technologies are also sufficient for its realization, but mostly it belongs to specialists in electronics and programming [3]. "Iron - Sensors - Microcontrollers Drivers - Computer (intelligent database) - Drivers - Iron "should be in a state of continuous dialogue. Such a chain needs software support, which provides a stable connection to the created system for process control [4]. Being overburdened with serial communication (sensors' survey and tasks execution are performed consistently by the microcontroller in real time), this chain loses its reliability and becomes more dependent on the owner's social status, electricity quality, the stability of its supply, the daily rate for its utilization and much more. Realizing the importance of all these facts, engineers pay close attention to the development of so-called Smart Systems [5]. In electrical networks, it is Smart Grid. Topologies, component communication, an arrangement of such systems are too complex and this is a separate issue, but they are based on "cultural" and economical consumption of electricity, and, therefore, energy resources in relation to their extraction. It is obvious that for support of Smart Refrigerators operation (by virtue of computer implementation) twice as much power will be needed, that doesn't comply with an overall objective of Smart System design. That's why some additional developments to address the issue of power consumption reducing (ideally by half for restoring the balance) are necessary. In addition, it is necessary to keep in mind the need for additional devices for monitoring the electricity consumption, the refrigerator operating state, the visualization of temperatures in the chambers and the 
efficiency of the refrigerator as a whole, which constantly confirm the work of Smart System.

\section{Methods}

Nowadays general requirements and expectations in the field of 'smart' technologies need high degree of reliability, efficiency and sustainability not only of the structure but also of the whole system [6].

We also should not forget about the system of service of complex systems, training of personnel of the appropriate qualification etc. An example is the introduction of power saving linear electric motors into the reciprocating compressor of modern refrigeration machines, which have an average operation life of not more than two years owing to the fact that a valve when moving to the upper dead point sometimes (at low load) collides with the cylinder head and collapses from impacts. This lack of them has been known for over 30 years but it remained unsolved. Sufficient in this example is the urgent need for an energy-saving electric motor, which will be different from a single-phase or three-phase asynchronous motor made according to the usual winding circuitry. It is known that the principle of the electric motor operation is based on the phenomenon of electromagnetic induction. The electric energy of the stator winding enters the moving rotor due to the magnetic field formed by the so-called reactive component of the stator winding current. The consumption of reactive power from the power supply network and its return in the opposite direction are carried out without losses in the form of heat; the useful work which it performs is zero, except for the small losses of power for magnetization of the steel magnetic core of the engine. In addition, reactive power at enterprises is measured by separate counters. And it would be all right, but the almost uninterrupted exchange of the reactive energy of the engine and the power supply network and the generator at the electric station is carried out by the current of the reactive magnetizing current in the wires and, in particular, through the electricity meter of the consumer, and, therefore, he pays for it. The reactive component of the full current increases the voltage drops in the wires of the power supply and reduces it to the end user (the most distant from the power station). This phenomenon is compensated by an artificial $10 \%$ increase in the supply voltage due to regulation on transformers, and therefore - the primary consumer has higher voltage. All this worsens the quality of power in the network. Considering the large-scale nature of reactive current consumption by home appliances, equipped with asynchronous motors, and despite the fact that consumers pay for its consumption, state policy and the commitment of electric power stations owners to supply high-quality electricity, require application for the power grids of electric power stations operating in the mode of generation of reactive capacitive power into a power supply network. Compensating power stations as well as generating ones are also energy consumers, and therefore are costly. There is another way - to increase the crosssection of wires in electric networks to reduce their active resistance, and therefore the voltage drop in them, but whether it is substantiated, it is the area for special discussion.

Summarizing the above-mentioned facts, it is possible to conclude that today the development of Smart Refrigerator should be conducted in the direction of continuation of power efficiency improvement of its refrigeration machine and its components, development, and equipment with devices for efficiency parameters monitoring, increase of reliability during the guaranteed by the manufacturer life cycle. The last two appear to be the most important issues to be solved because they determine and control the quality of the refrigeration appliance. Energy efficiency sometimes runs contrary to the quality parameters. The search for ways of their harmonization is the most important today's problem and it is connected with the introduction of innovative developments. Taking into consideration the "corporate" component in the products manufacture, the development of modern refrigerators is carried out by various manufacturers non-systematically from the global point of view. All of them, by the method of attempts and errors, are moving in one direction separately, relying only on their own developments, neglecting their careful analysis and having no access to the better models. When buying a car, the customer wants to have a powerful and economical engine, a good driving system, and then other amenities - a leather salon, air conditioning, electrical package, etc. So, let's look at everything, in turn, focusing on "own corporate" developments in the direction of preparing of the refrigerator to its equipment with Smart System facilities.

\section{Results A. Single-phase asynchronous motor of the
hermetic compressor drive}

Regardless of how we treat the method of determining the energy efficiency of the refrigerator operation, the combined amount of heat withdrawn outside from the useful volume of the cooling and freezing cabinets, electrical energy consumed for this by the compressor, achieved temperatures should be summarized in the composition of its parameter. As for heat flushes to the useful volume of cabinets from the outside through thermal insulation, in some cases, they reach $50 \%$ of the general capacity in the cabinets, and, as for electricity consumption, it depends on the power and energy perfection of the applied in the compressor composition asynchronous or another engine.

And, therefore, the wish of manufacturers to have a good and cheap thermal insulation and simple for producing electric motor are economically feasible levers and the main components of the expected profits. The single-phase asynchronous motor of the hermetic compressor drive is best suited for this. It is directly connected to the single-phase power supply networks of consumers, does not require complicated start and stop control, and has established itself by a non-failure operation. Disperancy with modern requirements in such parameters as specific power $(\mathrm{W} / \mathrm{kg})$, the coefficient of performance and power factor are considered as its shortcomings. In order for Ukraine to be able to sell electric motors on the world market, the product of the last two should be at the level of 0.8 , despite the fact that its existing values from the world producers are within the range of $0.25 \ldots 0.55$. It is suggested that the type of engine (one or three-phase), the diagram of the winding used on the stator, etc., have a significant influence on this parameter. Recently, scholars, not being able to provide its advanced values, prefer to supply a three-phase asynchronous motor as more energy efficient than single-phase one.

But assuming their useful power as a drive of the compressor with a capacity up to $250 \mathrm{~W}$, these motors are 
better than single-phase ones only because they enable speed control from the AC frequency converter controller.

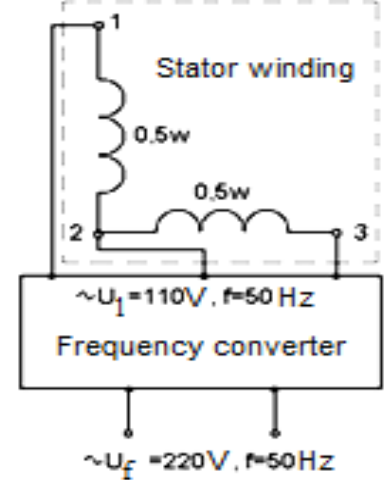

a)

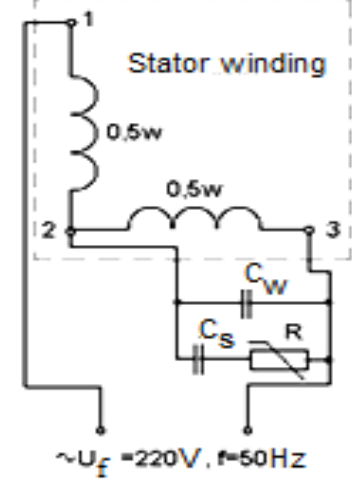

6)
Figure 1 - Schemes of the winding activation at feeding: a) from the frequency converter; b) from the one-phase network

Parameters of their efficiency and power factor are even worse than those of single-phase motors. For many decades, the schemes of manufacturing and incorporating of their technology in the production windings remain unchanged. For single-phase motors, it is with a starting or with additional windings. Despite the fact that single-phase asynchronous motors with start-up phase are the worst in terms of energy efficiency, they continue to be installed massively into compressors of refrigerators and air conditioners. Leading global manufacturers justify their choice by the goal of products costs reduce for the mass buyer, despite the fact that buyers will constantly pay almost double for the energy consumed by the engine. In addition, it is not a one-time payment, but rather accumulated, and the choice itself is a direct contradiction of the purpose and trend of the Smart System. Based on this, the task of single-phase motor improvement or even developing of a new pattern that will have higher production efficiency and power factor than the three-phase counterparts remains a priority.

The innovative model of such single-phase engine was developed at the Department of Electrical Engineering [7]. This single-phase motor is characterized in that its winding is made by a wound wire of similar cross-section in the form of a continuous coil designed for phase voltage supply $220 \mathrm{~V}$ with three taps and, inter alia, from the middle of the turns, that divides it into two identical parts. Each part of the coil is enclosed in half of the stator grooves in one layer with the overlap of the end sections and the formation of a spacious displacement angle of $90^{\circ}$. The applied winding is designed for power supply whether from three phases of the frequency converter after setting the initial value of its output line voltage $110 \mathrm{~V}$ at a frequency of current $50 \mathrm{~Hz}$, according to the scheme in Fig. 1a - for the ability to control the motor speed and compressor performance, or from single-phase voltage of $220 \mathrm{~V}$ at the frequency of current $50 \mathrm{~Hz}$, according to the scheme in Fig. 1b - without adjusting of the compressor's performance.

Improvement of the stator of motor-compressor unit is achieved through the expansion of its functionality and the unification of the winding (two stators in one); and allows to ensure the operation of the domestic refrigerator, as in the mode of controlling of the performance of its refrigeration machine when powered from the AC frequency converter, as well as in normal mode - without regulation. In this case, all the best technical and economic parameters of the stator and operating characteristics of the compressor of the refrigerator drive are maintained and are equal to the three-phase stator. The results of tests of the power characteristics of the serial and developed new engine with the stator supply from the single-phase network and in the composition of the sealed compressor NKV 10$3-\mathrm{K}$ (NORD) and are given in the table. If the AC converter becomes damaged, the motor-compressor unit receives direct power from a single-phase network with a phase voltage of $220 \mathrm{~V}$ and $\mathrm{AC}$ frequency of $50 \mathrm{~Hz}$, which makes it more reliable in everyday life and more repairable at the service centers.

Testing of the innovative single-phase stator as a part of the motor-compressor unit K-120 of refrigerator "Atlant" and NKV 10-3-K of refrigerator "Nord -239" confirmed its reliable operation with the constant performance of the refrigerating machine when powered from a single-phase network and in performance control mode - when powered by a three-phase AC Frequency Converter.

The results of the tests of motors according to the important energy indicators given in Table 1, verify the significant advantage of the new motor over its single- or three-phase analogs.

Table 1 - Units for magnetic properties

\begin{tabular}{|l|c|c|}
\hline Single-phasemotor & Serial & New \\
\hline Operating condenser & $\begin{array}{l}4 \mathrm{mF} \\
400 \mathrm{~V}\end{array}$ & $\begin{array}{c}18 \mathrm{mF} \\
200 \mathrm{~V}\end{array}$ \\
\hline $\begin{array}{l}\text { Consumption active power, } \\
P_{l}, \mathrm{~W}\end{array}$ & 122,1 & 120,6 \\
\hline $\begin{array}{l}\text { Consumption reactive power, } \\
Q_{l}, \mathrm{VAr}\end{array}$ & 42,48 & 1,59 \\
\hline $\begin{array}{l}\text { Net power, } \\
P_{2}, \mathrm{~W}\end{array}$ & 75,46 & 88,26 \\
\hline $\begin{array}{l}\text { Consumption current, } \\
I_{1}, \mathrm{~A}\end{array}$ & 0,681 & 0,561 \\
\hline $\begin{array}{l}\text { Power factor, } \\
\text { cos } \varphi_{\text {AM }}\end{array}$ & 0,815 & 0,995 \\
\hline $\begin{array}{l}\text { Motor efficiency, } \\
\eta_{A M}\end{array}$ & 0,61 & 0,715 \\
\hline $\begin{array}{l}\text { Rotor speed, } \\
n_{2}, \text { rev./min. }\end{array}$ & 2947 & 2962 \\
\hline $\begin{array}{l}\text { Available torque, } \\
M, \text { kg·m }\end{array}$ & 0,025 & 0,029 \\
\hline $\begin{array}{l}\text { Full power, } \\
S_{l}, \text { VA }\end{array}$ & 166,3 & 123,4 \\
\hline $\begin{array}{l}\text { Rotor sliding, } \\
s, \text { relative unit }\end{array}$ & 0,018 & 0,013 \\
\hline Boiling point of the refrigerant & $-20{ }^{\circ} \mathrm{C}$ & 1,53 \\
\hline $\begin{array}{l}\text { Refrigeration performance of } \\
\text { compressor NKV-10-3-K }\end{array}$ & 187,1 & 182,2 \\
\hline $\begin{array}{l}\text { Specific refrigeration } \\
\text { performance }\end{array}$ & & \\
\hline
\end{tabular}

\section{B. Multifunctional electricity meter}

Another important task, in particular, is the chain of software support, which provides a stable connection of the control system of the process of refrigeration appliance energy efficient operation, including the use of the Smart Diagnosis function. The solution of the problem is the automation of electricity consumption parameters diagnostics of electromechanical systems. Without its solution, it is impossible to approach to the real assessment of such important electromechanical system quality 
parameter as multiplication of the efficiency on power factor, and therefore the implemented methods, means, and technologies for reducing energy consumption.
The solution of this class of tasks is possible with the use of an element base of modern microprocessor technology.
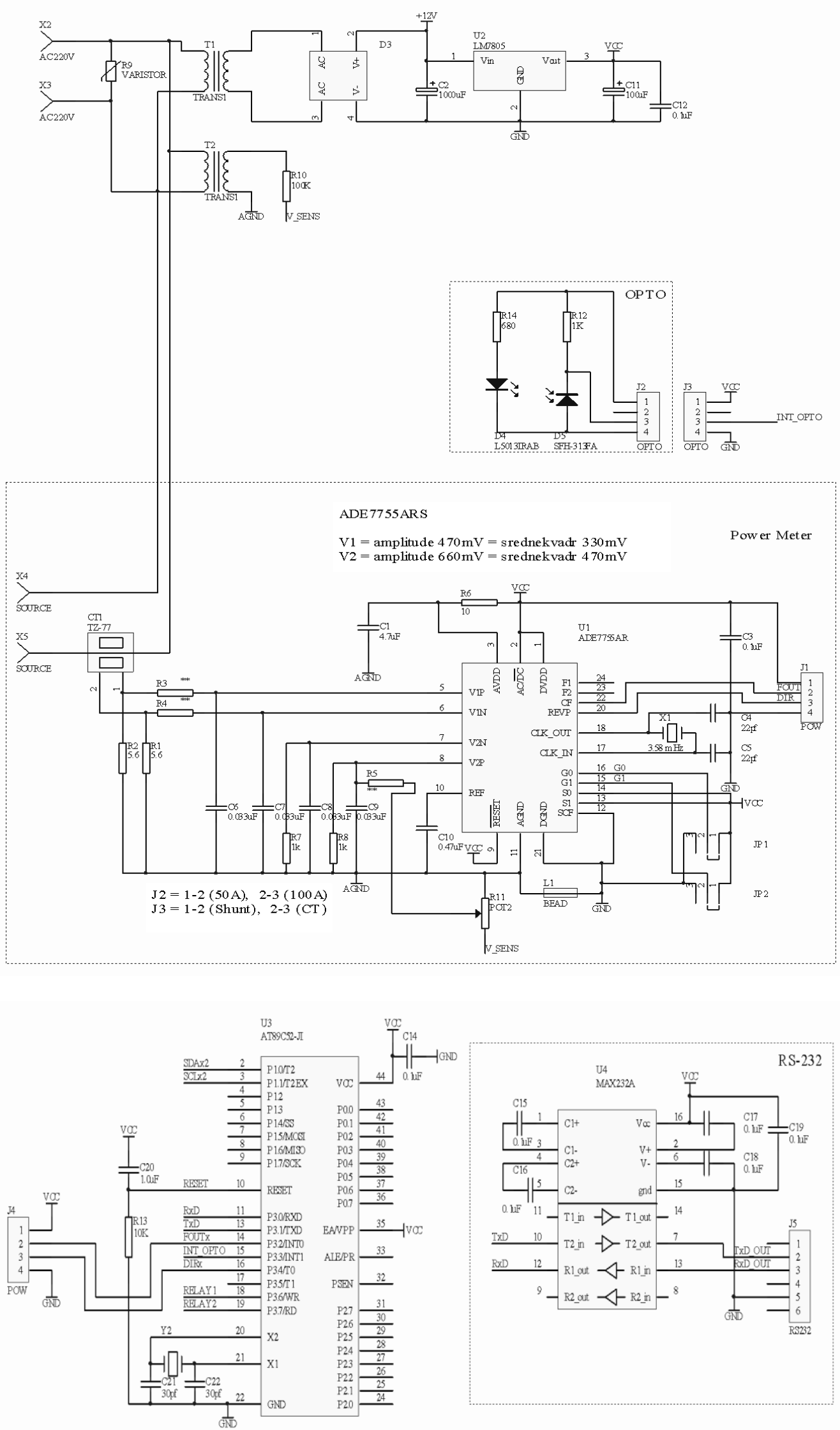

Figure 2 - Electrical circuitry of the power supply unit of ADE7755 meter, AT89S52 microcontroller and MAXIM232A driver 
Among the well-known integrated circuits of power meters with pulsed output, it is possible to recognize the chip of the ADE7755 Analog Devices manufacturer, whose specifications (output error $0,1 \%$ ) are lower than the requirements of IEC 688 .

The meter should be connected to the microcontroller to calculate the electricity consumed. If as the main advantage of the chips we accept the compatibility of the command system with a widely introduced Intel chip MCS-51, then the advantage should be given to chip AT89S52 - single-crystal microcontroller of ATMEL manufacturer Fig. 2 shows the basic electrical circuitry of the power consumption testing device performed on the basis of the ADE7755 meter, the AT89S52 microcontroller, and the MAXIM232A line driver-receiver. Multifunctional electricity meter, made in the form of a panel device is shown in Fig. 3 and is intended for testing of electromechanical systems of alternating current. The total list of tested and calculated variables consists of 46 names, which are grouped on the LCD display in 38 windows, as well as oscillograms, vector diagrams are built and harmonic analysis of the voltages and currents for single-, two-, three-phase load supply takes place.

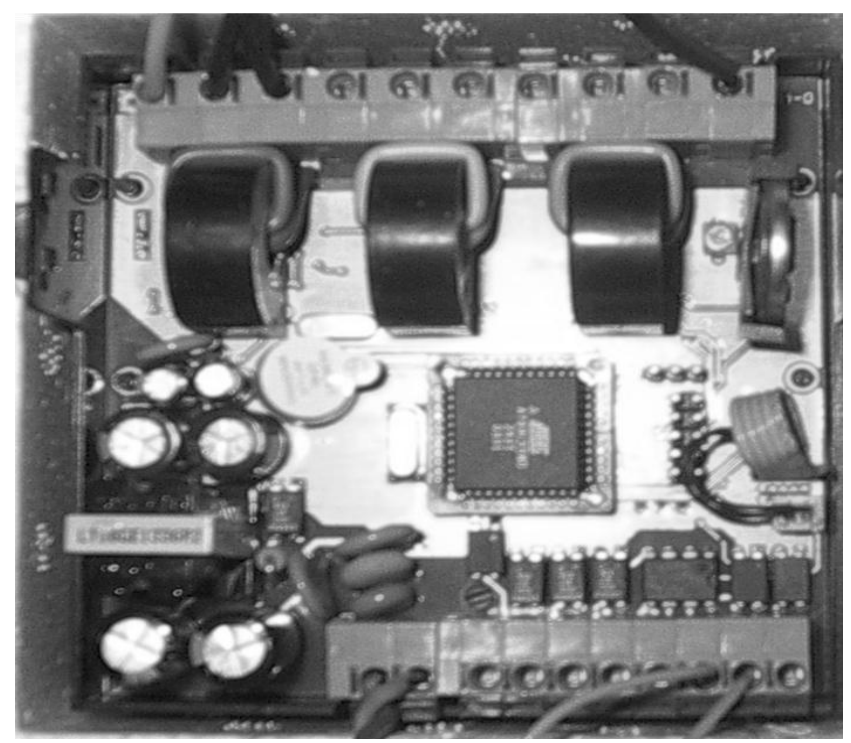

Figure 3 - The general view of the power meter, executed as shown in Figure 2 scheme

\section{Conclusions/discussion}

The efficiency of implementation of Smart Refrigerators development trend, operation reliability of home appliances - refrigerators, conditioners, etc., depends on the state of introduction into their topology of innovative developments of energy efficient components and testing equipment for many technical characteristics: temperature, humidity, heat flow, energy consumption, energy efficiency factors.

It is obvious that the most important contribution to the state of efficiency of the electrical device brings the electric motor and the compressor drive. Testing of the innovative single-phase motor proved its significant advantages for all parameters over the best world analogs.

Developed innovative device for testing the performance of energy consumption even if it has world counterparts, it does not concede to them. Equipped with a telecommunication output, it allows the exchange of information with devices of the highest level of the hierarchy like computer or data storage device, etc.

\section{References}

1. Miller, M.; Griendling, K.; Mavris, D. (2012) Exploring human factors effects in the smart grid system of systems demand response. In Proceedings of the International Conference System of Systems Engineering (SoSE), Genova, Italy, 16-19 July 2012.

2. M. Chan, E. Campo, D. Estève and J-Y. Fourniols, JY. (2009) "Smart homes - Current Features and future perspectives," Maturitas, vol. 64, 2009, pp. 90-97

3. Herold R., Vogel U., Richter B. (2010) OLED-onCMOS based single chip microdisplay and image sensor device, in Proceedings of International Display Workshop, pp. 339-340

4. Lee, J.S.; Chuang, C.C.; Shen, C.C. (2009) Applications of short-range wireless technologies to industrial automation: A ZigBee approach. In Proceedings of the Fifth Advanced International Conference on Telecommunications, Venice, Italy, 24-28 May 2009.

5. Wünderlich N.V. et al. (2015) “Futurizing' Smart Service: Implications for Service Researchers and Managers," J. Services Marketing, vol. 29, nos. 6-75, pp. 442-447.

6. Akhras, G. (2006) "Advanced Composites for Smart Structures", Proceedings, ICCM-12,12th International Conference on Composite Materials, Paris, July 5-9, 1999.

Baidak Yu. V. Odnofazna odnosharova obmotka [Singlephase single-layer winding]. Patent UA, no 48033. 